NASA Technical Memorandum 87611

\title{
SOME COMPARISONS OF US AND USSR AIRCRAFT DESIGN DEVELOPMENTS
} (NASA-TM-87611) SOME COMPARISONS OF US AND
USSR AIRCRAFT DESIGN DEVELOEMENTS (NASA)
36 P HC AO3/MF BO1.
(CSCL 01C

\author{
N86-16208 \\ G3/03 Unclas 05261
}

\section{LEROY SPEARMAN}

DECEMBER 1985

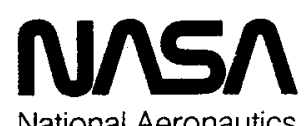

National Aeronautics and

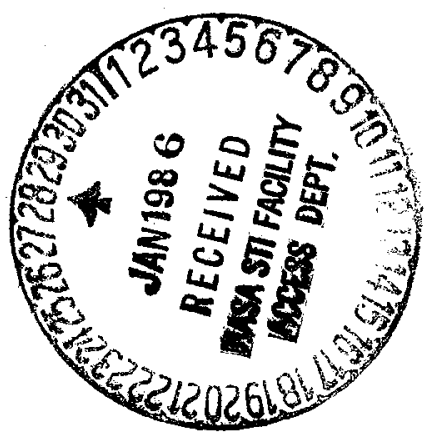

Space Administration 


\section{SUMMARY}

A review of US and USSR transport aircraft design trends indicates many similar characteristics. These design trends appear to be governed more by ideological differences rather than technological differences. The acquisition of western technology or the seemingly imitation of western products by the USSR does not necessarily reflect a lack of ability. It is not uncommon for the Soviets to accelerate their progress wherever possible through the use of work done by others that may be obtained either through open channels or by covert means.

\section{INTRODUCTION}

The development and advancement of aircraft of all types has been rather dramatic during the 20 th century. Although the first flight of a heavier-than-air powered manned airplane occurred in the US in 1903, the development and use of native aircraft in the US 7 agged somewhat behind the activity of other nations. Russia was active in the development of large aircraft prior to the Great October Revolution of 1917. Following the revolution, V. I. Lenin showed a deep interest in Soviet science including, specifically, the development of aviation. The US displayed interest in aviation prior to World War I but the native activity increased following the war. Some of the trends of the US and USSR aviation with particular emphasis on transport aircraft design and utilization will be discussed herein. While it is recognized that thorough coverage of all related activity would constitute an almost insurmountable task, it is hoped that most of the major points will be covered and that a greater appreciation for the magnitude of transport development, past, present, and future, will result.

\section{DISCUSSION}

\section{Early History}

USSR Large Aircraft.- During the days of Czarist Russia, it is reported in some Russion publications that a group of designers guided by $V$. A. Slyesaryeb in 1913 constructed a huge aircraft, the Svyatogor, with two engines of 450 horsepower; a wing area of 1,937 square feet (s1ightly greater than a $C-130$ Hercules), and a payload of about 14,300 pounds. This was followed by another large aircraft, the Russkii Vityaz. Although not generally mentioned in Russian documents, a young man named Igor Sikorsky in 1912 had the urge to build a huge flying machine. He was permitted to pursue the project by the Russian Baltic Company, for which he worked, and in 8 months the huge machine made its first flight from the airfield at St. Petersburg on May 13, 1913. Due to a strong French influence on aviation at the time, the Russian Baltic mechanics named the airplane Le Grand rather than its Russian name Bolshoi. The Grand was the first four-engine airplane (100 hp each) and the first airplane to have an enclosed cabin. The Grand weighed 7,000 pounds, had a wing span of 92 feet, and had 16 wheels to spread its weight over dirt fields. The cabin had four seats, a sofa, a table, a washroom, and a wardrobe for clothes. The Grand flew beautifully, 
logging 58 flights in 4 months. Then, while standing on the airfield one day, it was struck by an engine that fell off a small airplane flying overhead and was damaged to such an extent that it never flew again.

From it was developed the Ilya Mourometz four-engine bomber/reconnaissance in 1914, 80 of which were built and served the Czar's air force in World War I. The Ilya Mourometz weighed 10,560 pounds, mounted 8 machine guns and 1 cannon, and had an extremely effective bombing system. The only one that was lost in combat accounted for three German aircraft before succumbing.

Sikorsky fled to the United States following the revolution and became quite famous as a hel icopter designer. It might be fair to say, however, that his early work with large aircraft in Russia lead the way to future commercial transports as well as large bombers.

The Russian attraction for giant aircraft continued after Sikorsky had departed. It is interesting that the work was continued under the guidance of A. N. Tupolev--a name still prominently associated with 1 arge Soviet aircraft. Tupolev had been trained in the early $1900^{\prime}$ 's by N. Y. Zhukovskii who was called "the father of Russian aviation" by V. I. Lenin. Among others trained along with Tupolev were S.V. Illushin and A. S. Yakolev. Lenin kept a watchful eye on Russian aviation--he guided the use of aviation on the war fronts; he released resources for modernization of aircraft production plants; he issued instructions to Zhukovskij in December 1918 for the organization of the Central AeroHydrodynamic Institute (TSAGI); he issued a decree on air traffic which 1 aid the foundations for Soviet air 1 aw in January 1921; authorized domestic air travel in May 1921 and international air travel (Germany) in May 1922 using the Ilya Mourometz.

Tupolev became the head of a design team in 1922 that produced many aircraft types. Among the activities related to large aircraft were:

- First al1-metal aircraft, based on lessons learned from Junkers (Germany), included the ANT-2 (1924) and ANT-3 (R-3) (1926).

- The ANT-4 (TB-1), built in 1925, was a twin-engine heavy bomber with a low cantilever wing, clearly derived from Junkers, that could carry a maximum payload of 3.5 tons or 1 ton of bombs for a range of 850 miles. The TB-1 was the first airplane to be equipped with boosters for reducing the takeoff distance. The TB-1 set the pattern for large Soviet heavy bombers through the $1930^{i} \mathrm{~s}$. At the end of its military 1 ife, the ANT-4's were turned over to the Civil Air Fleet (about 1936).

- The ANT-9 (PS-9) was an a11-metal trimotor ten-passenger airplane introduced into airline service in May 1929.

- The ANT-6 (TB-3) was a heavy four-engine bomber that entered service in 1932 , several years before the American $B-17$. The TB-3 weighed about 40,000 pounds and could carry a maximum of 5 tons of bombs or 2 tons of 
bombs for a range of about 1,550 miles. The TB- 3 was al so used to transport paratroopers and in maneuvers at Kiev in 1936, in front of foreign military observers, a fleet of TB-3's disgorged some 600 paratroopers.

- The ANT-16 (TB-4), designed to carry about a 10-ton bomb load (twice that of the $T B-3)$, had six engines--four mounted on the wing leading-edge and two mounted in tandem above the fuselage. The wing span was about 180 feet. The maiden flight was made on July 3, 1933, but serious vibration problems of the aft body and tail brought the program to a halt by September.

- The ANT-14 Pravda was a huge 5-engine 36-passenger aircraft (about 1932) that was used in airline service for 10 years.

- The ANT-20 Maxim Gorky, 1934, was a giant 8-engine 80-passenger aircraft with a 206.6 foot-wing span and weighing about 116,000 pounds. Intended for propaganda, the airplane had lights under the wing for spelling out slogans, a printing press for printing handbills to be distributed in flight, a photo $1 \mathrm{ab}$, a telegraph office, a 16-telephone exchange, and motion-picture projectors. It was rammed in midair in May 1935 by an escorting airplane with the loss of 35 lives. A second version of the ANT-20 having only the six wing-mounted engines was built in 1938 and served as a military transport until it crash-landed in December 1942.

- The ANT-22 (MK-1) Sea Cruiser was a twin-hulled six-engine flying boat built as a heavy bomber for the Navy in 1934. Although never accepted by the Navy, the ANT-22 flew successfully and set several load-to-height records in 1936.

- The ANT-25 was an unusual Tupolev design with a single $V-12$ engine of 950 horsepower, a retractable 1 anding gear, and a low wing having a span 2.5 times the body length. Intended for range and endurance, the ANT-25 set many records including one for 7,712 miles in 75 hours in 1934 .

There had been other large aircraft disasters prior. to the Maxim Gorky raming. In November 1933, a Kal inin K-7 7-engine flying-wing aircraft crashed with a loss of 15 lives after a structural failure of one of the twin booms that supported the tail. Further work on two more $k-7^{\prime} s$ was suspended. Other adventurous projects that were terminated included a S. G. Kozlov design for a 12-engine flying-wing tank transporter with rear-ramp access and other Tupolev designs, the ANT-26 (TB-6) bomber and the ANT-28 military transport, that would have had 12 engines and weighed about 70 tons. By 1936, the decision was made to terminate further work on super-heavy aircraft.

Some Foreign Connections.- In the $1920^{\prime} \mathrm{s}$ and $1930^{\prime} \mathrm{s}$, Russian aircraft design was fed not only by indigenous talent but by some foreign connections. The German influence is readily apparent in the works stemming from Junkers and in the use of some BMW engines. Some engine designs were based on the French Lorraine and 
imported Gnome-Rhone Jupiters which were themselves a licensed version of the British Bristol Jupiter. Hispano-Suiza engines were al so reproduced in Russia. A US connection was established when a Soviet delegation, including Tupolev, visited the USA in 1929 and managed to obtain a number of 600 horsepower Curtiss Conquerer inline engines that were used on some Soviet prototype aircraft. A second delegation to the USA in 1932 secured manufacturing rights for the 700 horsepower Wright Cyclone 9-cylinder radial engine from which was subsequently developed the 14-cylinder twin-row radial Wright Cyclone as well.

In 1936, ironically, during a period of self-containment, the United States permitted Soyiet technicians to visit the Douglas Aircraft Company and granted manufacturing rights for the revolutionary $D C-3$ design to the USSR. The Soviet version of the $D C-3$ was then produced under the direction of $B$. P. Lisunov as the Li-2 and was soon placed in airline service where it remained until well into the mid $1940^{\prime} s$.

US Large Aircraft.- Al though the Wright brothers achieved manned flight with a heavier-than-air machine at Kitty Hawk, North Carolina, on December 17, 1903, the feat was essentially ignored in the US. The prestigious Scientific American did not acknowledge the flight until 3 years later in December 1906. Other nations, notably France, England, Germany, Italy, and Russia, were moving ahead in aviation developments. Other US designers and experimenters of note who followed the Wrights during the 1900's were Glenn H. Curtiss and Glenn L. Martin. While no extremely large aircraft such as those built in Russia were conceived in the US during the early $1900^{\prime} \mathrm{s}$, there were some developments that should be mentioned:

- Curtiss America - a 1914 twin-engine biplane flying boat with an enclosed cabin that was intended to fly the Atlantic. The problem of how to get enough fuel on board for such a flight was not solved before World war I broke out and intervened with the effort.

- NC-4 - another Curtiss biplane flying-boat with four Liberty engines of 400 horsepower each. The $N C^{\prime}$ 's weighed about 28,000 pounds (43 percent of which was useful load), had a wing span of 126 feet and a wing area of 2,380 square feet. The first flight of a NC was made in October 1918, only weeks before the Armistice was signed. The .NC-4 did make a multistop first crossing of the Atlantic in May 1919.

- Martin MB-1/MB-2/NBS-1 were relatively 1arge twin-engine biplane bombers developed and produced by the Glenn L. Martin Company near the end of World War I but too late for combat. The MB-2 was used at Langley Field, Virginia, in 1921 for the famous Billy Mitchell bombing demonstrations in which a destroyer, a cruiser, and finally a battleship, all captured from Germany, were bombed from the air and sunk. The MB-2 could carry up to 2,000 pounds in bombs, had a normal gross weight of almost 14,000 pounds, a wing span of about 74 feet, and a wing area of 1,211 square feet.

- Curtiss B-2 Condor, similar in appearance to the Martin MB-2, had a bomb load capacity of 2,500 pounds, and a combat radius of 300 miles at a speed 
of 100 miles per hour. Considered too costly, only 12 were procured in 1928-29. A later version of a Curtiss Condor twin-engine biplane equipped with passenger sleeping quarters was purchased by American Airlines in 1933. A military transport version, VC-30, was al so produced.

- Keystone bombers were yet another twin-engine biplane built to replace the Martin's in 1928. Keystones (B-3 through 6) had radial Pratt and Whitney engines. An earlier version, LB-5A, developed originally from the large single-engine Huff-Dal and bomber had Liberty engines. The Keystone wing span was 75 feet and they weighed about 13,000 pounds.

- The US was not without some unusual designs for large aircraft in the early 1900's. One incredible machine was the Jones multiplane, a sevenwing, three-engine monstrosity conceived in 1916 by Herbert $F$. Jones of the American Multiplane Company. The aircraft actually flew in 1919-20 at Langley Field but was too heavy and out of bal ance. The Army purchased the machine for one dollar in June 1920, dismantled it in September, and wrote it off the books.

- Another unusual design was the Lowe, Willard, and Fowler L. W. F. Model H "OWL." Intended as a long-range night-mail plane when construction started in 1919, the airplane was evaluated as a bomber at Langley Field in 1921-22. The "OWL" was a large biplane with three Liberty engines--two mounted on twin-tail booms and one mounted on a centerbody that al so housed a crew of three. Performance was adequate but not impressive, $L$. W. F. was forced to liquidate and the "OWL" was scrapped in 1923.

- Barling NBL-1 was a giant bomber triplane with six engines--four tractor and two pusher--ordered by the US Army in the early 1920's as a supplement to the Martins. Intended as a night bomber with an internal bomb load of 5,000 pounds and a crew of 6, the Barling first flew August 22, 1923. only one was built, little fiying was done, and the $\$ 350,000$ monster was scrapped in 1928.

Some Foreign Connections.- The US was not wi thout foreign connections in the development of aircraft. In the area of large aircraft, some of these were:

- Caproni (Italy) Ca33 bomber, mainstay of the Italian bomber force, came to Langley Field for flight tests in 1917. The Ca33 was a large biplane with three engines--two tractor engines mounted on the front of twin-tail booms and one pusher engine mounted on a centerbody that housed a crew of three. Production orders were placed with 2 American companies for 500 bombers but only 5 were built.

- The Handley-Page (British) 0-400 was a large twin-engine biplane heavy bomber used by the British from 1916 throughout World War I. An American built version substituted Liberty engines for the British Rolls-Royce. About 8 were assembled in this country and another 100 were shipped overseas unassembled. 
- Fokker (Dutch) provided several large aircraft to the US including the single-engine T-2 transport with a 79.5-foot span cantilevered high wing. After much difficulty, a T-2 with Lts. Kelly and Macready of the Army Air Service made the first nonstop trip across the US from New York to San Diego in 1923. A Fokker C-2 trimotor, capable of carrying 10 passengers, was used by the Army Air Service. The C-2 type was used by Adm. Byrd on an over the North Pole fiight in 1926 and by Army flyers on a historic California to Hawaii flight in 1927. The Fokker trimotor was al so used by what was to become Pan American Airways on Key West to Havana service beginning in 1927 .

- Fokker (General Aviation) $C-14$ was a single-engine high-wing transport with an enclosed cabin for six and an open cockpit for the pilot. It was in service with the Army from 1933 through 1936.

- Sikorsky, the Russian immigrant, produced such passenger aircraft as the S-38 10-passenger twin-engine amphibian, the 32-passenger 4-engine $S-40$ Souther Clipper amphibian, and the 1arger S-42 4-engine 32-passenger flying boat--a11 designed especially for Pan American Airways.

\section{Organization}

A brief overview of the governmental structure of the USSR and US, particularly as related in aviation, follows. Some understanding of this structure is useful to any attempt to compare developments in the two countries.

USSR Government.- The government of the USSR is an interlocking organization of three principle bodies performing particular functions, namely:

- Political - the Communist Party of the Soviet Union through the General Secretary of the Communist Party, the Politburo, and the Central Committee develops the national policy and represents the pinnacle of power in the USSR.

- Legislative - the national legislature, or Supreme Soviet, elects a presidium, or executive committee, whose chairman is the USSR chief of state.

- Administrative - the Supreme Soviet, with the approval of the Party, appoints the Council of Ministers which administers national policy.

Council of Ministers.- The Council, through a presidium, elects a chairman who $i$ s the nation's chief executive officer. Within the Council are some 62 ministries that control all facets of national affairs. Five of the ministries have an involvement in the aviation industry. These are: 
- Ministry of Defense - directs all military forces, maintains weapon research institutes, and has procurement priority over all other ministries.

- Ministry of Civil Aviation - directs procurement of nonmilitary aircraft and controls the national airline, Aeroflot.

- Ministry of Aircraft Industry - directs the research, design, and production of aircraft.

- Ministry of Higher and Specialized Education - directs various educational and research institutes which supply most of the engineers and technicians for the aviation industry.

- Ministry of Foreign Trade - directs foreign sales including aircraft sales transacted through the aviation export office, Aviaexport.

Ministry of Aircraft Industry.- The Ministry of Aircraft Industry comprises several institutes responsible for almost all research, design, and production of aircraft:

- The Central Aero-Hydrodynamics Institute (TSAGI), which conducts basic aviation research in its laboratories and wind tunnels and uses this research to establish aerodynamic methods and forms.

- The Scientific Research Institute for Aircraft Equipment (NISO), which sets standards for the instruments, avionics, and accessories required by the aviation industry and tests this equipment before delivery.

- The All Union Institute of Aviation Materials (VIAM), which is responsible for and must approve the type, proportion, and usage of materials in aircraft.

- The Flight Research Institute (LII), which investigates flight dynamics and contains facilities, pilots, and flight-test equipment for flight research.

- The Scientific Research Institute for Aviation Technology and Organization of Production (NIAT), which manages the plants that produce aircraft engines, materials, and equipment and that assemble aircraft.

- The Central Institute of Aviation Motor Building (TSIAM), which directs several experimental-design bureaus charged with design and development of aviation power plants.

- The Central Design office (TSKB), which directs several experimentaldesign bureaus doing detail design and construction of prototype aircraft. 
The many organizations controlled by the Ministry of Aircraft Industry perform the functions that, in the US, are done independently and separately by the government (military, NASA, etc.), industry, and academia.

The Central Design office.- The experimental-design bureaus (OKB) under the Centrat Design office are colTectives that design and construct prototype aircraft of various types. Currentiy, the primary OKB's are:

Antonov (An) - transports, sailplanes

Beriev (Be) - seaplanes, transports

Ilyushin (I1) - transports

Kamov (Ka) - hel icopters

Mikoyan/Gurevich (MiG) - fighter/interceptor

Mil (Mi) - hel icopters

Sukhoi $(S u)$ - attack, fighters, interceptors

Tupolev (TU) - bombers, transports

Yakovlev (Yak) - sports planes, fighters, transports

The transport design bureaus and some of their products are shown in Figures 1 and 2 .

US Government.- The contrasts between the US government and the USSR government would require a lengthy discussion. However, the differences, as related to this paper (that is, the development of aircraft) are relatively basic:

- Within the USSR there is centralized control within the government of all aspects of national needs, requirements to be met, resources to be allocated, training required, research and development, production, testing, operation, and so on.

- Within the US there is considerable discussion, principally between the executive and legislative branches of the government relative to national needs, requirements, and resources. Matters of training, research and development, production, testing, and operation (at least commercial operation) are open to competition in the public sector of business, industry, and academia. In addition, there are government agencies that function as advisory or regulatory bodies (such as FAA and CAB) and the independent agency for research, development, testing, experimenting, and evaluating which began as NACA in 1915 and evolved into NASA in 1958.

An illustration of some U.S. transport types over the years is shown in Figure 3 .

\section{Airline Developmental History}

USSR Developments.- The USSR began some experimental air service in 1921 and 1922 , the first service being with the joint Soviet-German airline Derulfut using Fokker F.III single-engine monoplanes. This service continued to operate until 1937. Three undertakings in 1923 were Dobrolet, Ukrovdukhput, and Zakavia. 
Subsequently, the three became merged as Dobroflot in 1930. In 1932, the national airline Aeroflot was created. Until the German invasion in June 1941, Aeroflot gradually built up its route system.

During the war, Aeroflot was engaged in essential military tasks and, following the war, continued to expand again. Aeroflot growth is shown in the following:

\begin{tabular}{|c|c|c|c|}
\hline Year & Route Miles & Passsengers & Cargo, Metric T \\
\hline $\begin{array}{l}1940 \\
1970 \\
1974 \\
1978 \\
1980\end{array}$ & $\begin{array}{r}90,906 \\
773,000 \\
824,000 \\
908,000 \\
1,000,000\end{array}$ & $\begin{array}{r}359,000 \\
71,400,000 \\
90,500,000 \\
97,800,000 \\
103,800,000\end{array}$ & $\begin{array}{r}445,000 \\
1,844,000 \\
2,231,000 \\
2,847,000 \\
2,989,000\end{array}$ \\
\hline
\end{tabular}

Aeroflot now serves 110 cities in 86 countries and links 3,000 cities and towns within the USSR.

US Developments.- The US lagged somewhat behind other nations in establishing air service. Ryan Airlines opened a Los Angeles-San Diego Air Line on March 1, 1925, operating with Standard biplanes and the Douglas Cloudster. Through the later half of the $1920^{\prime} \mathrm{s}$, some 30 or so airlines came into existence. Many of these 30 had been absorbed by mid-1931 into four major US airlines - American, Eastern, TWA, and United. Other prominent early airlines were:

- Western Airlines began as Western Air Express in July 1925.

- Delta Airlines, as Delta Air Service, flew passengers regularly beginning on June $1,1929$.

- Northwest Airlines was incorporated as Northwest Airways on August 1, 1926, and began operations on October 1, 1926.

- Pan American World Airways emerged on March 14, 1927, from three groups seeking service to Cuba, Latin America, and South America.

- Continental Airlines came into being during 1937. from some earlier origins of Varney Speed Lines which had begun operations on July 15; 1934.

- Braniff began operations originally on June 20,1928 , but in recent years has suffered some difficulties.

- National Airlines began operations on October 15, 1934, but in recent years has succumbed.

- Piedmont Aviation was incorporated as a sales and service operation on July 2, 1940. An airline division, Piedmont Airlines, was formed as a regional carrier with the first commercial flight on February 20, 1948. Following airline deregulation in 1978, Piedmont has shown tremendous growth and became a major carrier by 1984 . 
- US Air, 1979, began as Al leghany on March 5, 1937.

- Frontier Airlines had its beginning on November 27, 1946.

- Republic Airlines (April 26, 1979) came from a merger of Southern Airways (Apri1 1929) and North Central Airlines (which had begun in 1944 as Wisconsin Central Airlines).

There are many other US airlines that could be listed but, suffice it to say, that the airline structure is extensive and somewhat complex. Any sort of comparison between USSR and US airline operations should be undertaken only with great care because of the fundamental differences under which the two systems exist, that is, socialism and capitalism.

\section{USSR Design Traits}

Tupolev Designs Since 1945.- Some illustrations will be given that may provide an insight into some Soviet design characteristics. Versatility and continuity within the design bureaus can be illustrated with Tupolev OKB (Fig. 4). Tupolev began post-WW II large aircraft development by copying the US B-29, three of which were forced down in the Soviet far east in 1944. The resuitant copy, Tu-4, appeared at the Tushino Air Show in 1947. A civilian version was also built but not produced. A considerably larger bomber version, the Barge, al so evolved. Then, proceeding from straight-wing piston-engine designs, Tupolev developed the twin-jet swept-wing Badger bomber and the large turboprop swept-wing Bear bomber. The Badger al so evolved into the world's first swept-wing jet civil transport, the Tu-104, while the Bear evolved into the Tu-114 civil transport and the Tu-126 AWACS. In about the same time period, Tupolev developed the twin-jet Backfin medium bomber which became the Tu-28 Fiddler longrange interceptor, and the more highly swept-wing Tu-22 Blinder Navy bomber. The Backfin, Fiddler, and the Bl inder also marked a step into the supersonic flight regime. Having gone into the supersonic realm with highly-swept fixed wings, with which some inherent stability problems may occur, Tupolev turned his attention to other supersonic designs utilizing the double-delta Tu-144 Charger and the variable geometry Backfire. Subsequently, the larger variable geometry bomber Blackjack was discovered by the West in November 1981.

Recent Tupolev Developments.-- Since the mid 1960's, Tupolev has developed three large supersonic airplanes using two different design approaches. The TU-144 Charger A was introduced as the Soviet SST and on December 31, 1968, made the world's first flight for a supersonic commercial transport. The Charger $B$ was an advanced version with a new structure and improved propulsion system and is thought to be the system identified as Aircraft 101 with which several FAI world speed, payload and al titude records were set in July 1983. These records include flight at about $M=1.9$ at an al titude of about 60,000 feet with payloads up to about 66,000 pounds. This leaves open the possibility that another advanced version of the basic Charger airframe may yet appear. The Backfire A which was first identified in the late $1960^{\prime}$ 's has al so gone through various structural and propulsion changes in the $B$ and $C$ variants in which, most likely, improved 
performance has been attained. The Blackjack appears to be a possible melding of designs with aerodynamic features similar to Backfire and a propulsion system that may be similar to Charger.

USSR Long-Range Bomber Developments.- Much of the bomber development during 1945-54 (Fig. 5) was done by the Tupotev OKB as previously shown, proceeding from the Bul1 (Tu-4 B-29 copy) to the Badger and Bear. An element of competition was introduced through Myasishchev, however, with a 1arge straight-wing propellerdriven project $M-13$, an airplane that was not produced, and the Mya-4 Bison fourjet strategic bomber. From the extent of service and the number produced, it is clear that the turboprop Bear was favored over the turbojet Bison.

Bomber developments since 1954, with the advent of supersonic capability, (Fig. 6) has also been dominated by Tupolev with the Backfin (Fiddler) design, the Backfire, and the Blackjack. Myasishchev did produce a four-jet delta-wing supersonic bomber design, the Bounder, that was revealed in the 1961 flyby but was never produced. The four-jet strategic bomber has apparently reappeared now as B1 ackj ack.

Prototype Development.- Some USSR developments, as we have seen, begin with prototypes on hand--for example, the $D C-3$ to the $L i-2$ and the $B-29$ to the Tu-4. However, the Soviets often use components from existing aircraft as part of the development of new aircraft. In addition, when sufficient flight-proven components do not exist, the soviets have used flying test beds as an aid to design development. Two examples are 111 ustrated in Figures 7 and 8 . The variable geometry outboard wing-pivot concept was first seen on a Fitter airframe in the 1967 airshow (Fig. 7). The planform is essentially identical to the wing that appeared in Backfire in 1969 and, subsequently, on Blackjack. In this case, the modification to the Fitter wing was so effective that it was permanently adapted to the fitter series of fighter.

Another example of the use of a small-scale flying test bed was in the development of the double delta planform for the Charger airplane. The wing planform was first tested on a modified MiG 21 Fishbed (Fig. 8). In this case, the modification was not adapted to the Fishbed series of fighters since it is not likely that any performance gains would be realized.

\section{Transport Aircraft}

USSR Transports.- During World War II most Soviet aircraft being produced were fighter types. The Douglas DC-3 which was being produced as the Li-2 was the backbone of Aeroflot and, in particular, the workhorse in military airlift. Following the war more attention was given to new transport designs.

The major design bureaus for transport aircraft are Antonov, Beriev, 17 yushin, Tupolev, and Yakolev. These OKB's are shown in Figure 1 with some of their major products. Plan views are compared for the principle current transports in Figure 2. Neither space nor reason permits comment on the many 
aircraft produced. However, some points to be noted in essentially a chronological order are as follows:

- ANT-2 Colt was Anotnov's first postwar transport design (1947). It is a single-engine propeller-driven biplane with an enclosed cabin for up to about 14 passengers or troops. The design won Antonov a Stal in Prize in 1952. Since then he has concentrated on large turbine-powered aircraft.

- I1-12/14 are propeller-driven airplanes somewhat similar to the US DC-3/C47 except for more powerful engines and a higher speed. These were the first postwar Soviet transports and were introduced into service in 1947 with Aeroflot and as military transports as early replacements for the Li-2.

- Tu-104, the world's first swept-wing jet transport test flown in 1955, was a derivative of the Tu-16 Badger bomber that first flew in 1952. This is representative of the means that the Soviets have frequentiy used to place new civil designs into production more quickly than the West.

- An-8 was the first Soviet airplane designed for tactical airlift. It has twin turboprops and carries about 40 passengers or troops.

- I1-18 is a four-engine turboprop, introduced in 1958, that had a seating capacity of $80-110$. It was one of the first airplanes to have a forward entrance door. A maritime reconnaissance version $11-38$ is also in service.

- An-10/12 is a four-engine turboprop design capable of carrying up to 100 passengers or troops. The $A n-10$ is a passenger version while the $A n-12$ is" a freighter version in service with both Aeroflot and the military (VTA).

- An-14 is a high-wing twin-piston engine design for about 8 troops. It is distinguished by an exceptionally high-wing aspect ratio of about 12 . An28 appears to be a later modification with twin turboprops and an extended body to accommodate about 15 passengers and an increased payload.

- Tu-114 was a transport conversion of the Tu-95 Bear that made an appearance a the 1959 Paris Air Show. The airplane could seat up to about 220 passengers and for a number of years was the largest airliner in service. The propellers were eight-bladed contrarotating with a diameter of 18.375 feet. Maximum gross weight was 385,805 pounds and cruising at $470 \mathrm{mph}$, it was the fastest propellor-driven airliner ever in service.

- Tu-124 was a scaled-down version of the Tu-104 originally designed in the 1 ate 1950 's as a replacement for the prop-driven I1-18. Designed for operation from small fields, the Tu-124 had double-slotted trailing-edge flaps, upper surface spoilers, and a large air brake beneath the center section to steepen the glide path. 
- Tu-134 was a subsequent replacement for the Tu-124 with twin jets aftmounted on the fuselage. It first flew about 1963-64 thus being contemporary with the BAC 111 and Douglas DC-9.

- An-22, a major component of the VTA, is a four-engine turboprop with a high wing having an aspect ratio of about 12. The maximum gross weight is about 550,000 pounds. A maximum payload of about 176,000 pounds $c$ an be carried about 3,100 miles and with a payload of about 100,000 pounds, the range is extended to 6,800 miles. A civil version of the An-22 appeared in Aeroflot markings at the Paris Air Show in 1965. The civil version is said to have a capacity of 300-350 passengers.

- An-24/26/30 twin turboprop in passenger version (up to about 50), freight version with payload of about 13,000 pounds, and reconnaissance version. First to use Antonov unique rear loading ramp which serves as underside of body when closed and can also be slid forward to facilitate direct floor loading and air dropping.

- 11-62 was designed to replace the Tu-114 on 1ong haul routes. With four rear-mounted engines, it resembles the BAC VC-10. Normal seating is 186. The 11-62 first flew in January 1963 and it entered service in March 1967 .

- Yak 40 was designed to meet the needs for small field local service operation and replace older aircraft such as the $L i-2$ and $11-14$. The Yak 40 is a tri-jet (similar to a small B-727) and carries about 32 passengers. It first flew in October 1966 and went into service in September 1968. Many have been exported.

- Be-30 is another small field operator having twin turboprops and a seating capacity for about 15 passengers. It is intended to replace the $A n-2$ and can take off in about 1,800 feet from dirt fields.

- Tu-154 is a medium-haul transport that has three jets (similar to B-727). Passenger capacity is about 164 . First f1ight was october 4, 1968, and it entered service in November 1971.

- I1-76 is similar to the Lockheed C-141 with a maximum payload capacity of about 88,000 pounds and a maximum gross weight of about 375,000 pounds. Designed as a military transport, it al so serves in Aeroflot. First flew in March 1971 and appeared at the Paris Air Show in June 1971 (in Aeroflot colors). The $11-76$ is especially designed for operation from unprepared fields.

- Yak 42 is a 120-passenger trijet for feeder 1 ine service that first flew in March 1975.

- An-72 is a STOL design with blowing over the wing somewhat similar to the Boeing $Y C-14$. It was shown at the 1979 Paris Air Show. The maximum 
payload is about 22,000 pounds and there are provisions for up to about 32 passengers. The An-72 set 16 records for height, time to height, and payload to height in November-December 1983.

- I1-86 is a wide-body four-engine jet with a passenger capacity of 350 that went into service in July 1981.

- Tu-144 was introduced as a supersonic transport and became the world's first SST to fly on December 31, 1968. One appeared at the Paris Air Show in 1973 where it was lost in a flight accident. Limited cargo service began in December 1975 but passenger service was never established. Civil supersonic operation has, for the time being, been suspended.

- An-124 is Antonov's first large jet and apparently the largest airplane flying in the world today. Designed as a military transport, it appeared at the Paris Air Show in Aeroflot colors in June 1985. It is similar to the C-5A except for the low horizontal stabilizer. The payload is as much as 330,688 pounds with a maximum takeoff gross weight of about 893,000 pounds. Range with maximum payload is said to be about 2,800 miles. The An-124 includes many features to aid in loading and unloading and has an extensive array of flaps and spoilers to facilitate low-speed flight and short-field operation.

- I1-96, a large capacity transport reportedly under development that may make use of such features as a variable-camber wing similar to that being developed by Airbus. The 11-96 would be similar to the 11-86 but have greater weight, a better wing, improved propulsion, and increased range.

US Transports.- Many manufacturers have contributed to the US transport aircraft fleet. Though many omissions are likely, some designs will be noted as follows:

- Ford 2-AT, an al1-metal single-engine propeller-driven aircraft, began mail service in April 1925 and passenger service in February 1926.

- Ford Trimotor first flew in June 1926. The original 4-AT could accommodate 11 passengers and this was followed by the 5-AT-with up to 15 passengers.

- Boeing Model 40 single-engine biplanes flew mail and two passengers in 1927 and up to four passengers in 1929.

- Boeing Model 80 was a trimotor biplane that appeared in 1928 with a seating capacity of 12 . The Model $80 \mathrm{~A}$ upped the capacity to 18 passengers.

- Stinson Trimotor was introduced in service in September 1930. 
- Curtiss Condor, a twin-engine biplane, entered service in December 1930. Original version had 18 seats, a later version had provisions for 12 in sleeping berths.

- Boeing Monomail Model 200 and 221 were built in 1930 for mail, cargo, and passenger service. These were all-metal single-engine low-wing monoplanes with an open cockpit for the pilot and an enclosed cabin for up to eight passengers on the Model 221A. Experience on the Monomail led to the design of the Boeing 247.

- Boeing 247 was a landmark in transport development. The airplane was a ten-passenger low-wing all-metal monoplane with retractable landing gear. It first flew on February 8, 1933, and was in service with what eventually evolved into United Air Lines.

- Lockheed Vega was designed in the late 1920's as an outgrowth of the belief that a market existed for a smal1, high-speed passenger airplane. Designed by John Northrop and Gerrard Vuitee, the first Vega was a very clean, streaml ined, high-wing cantilever monoplane with wheel fairings (pants) and a NACA engine cowling. Four passengers could be carried at up to $185 \mathrm{mph}$. Most Vegas were made of plywood and were very strong and smooth. The first flight as made on July 4, 1928, and subsequently, was used by others including TWA and Braniff.

- Lockheed Orion was a six-passenger, single-engine, low-wing monoplane with retractable landing gear. The orion went into service in May 1931 and flew at speeds up to $200 \mathrm{mph}$.

- Vultee $V$ - $1 A$ was a single-engine low-wing monoplane with retractable 1 anding gear and carried 8 passengers at $211 \mathrm{mph}$. American Airlines introduced the $V-1 A$ in September 1934 .

- Flying boat activity was significant during the 1930's primarily because of oceanic routes of PAA. In addition to the Sikorsky aircraft, S-38, $S-40$, and $S-42$ previously mentioned, PAA placed in service flying boats produced by Martin and Boeing. The Martin M-130 China Clipper was a 4 -engine flying boat weighing a little over 52,000 pounds and carried 46 passengers and a crew of 8 . The M-130 went into Pacific Service November 22, 1935. The Boeing 314 Yankee Clipper went into service in 1939. The 314 was a 4-engine fiying boat weighing 82,400 pounds and carried 74 passengers and a crew of 10 . In about the same time period, Martin produced the Mars as a cargo/transport/patrol flying boat for the US Navy. Ordered in 1938 and in service through the $1940^{\prime} \mathrm{s}$, the Mars weighed 145,000 pounds. Several records were set by the Mars including carrying a payload of 20,500 pounds for 4,700 miles in 1944 and carrying 301 passengers plus a crew of 10 in May 1946.

- DC-1 was produced in July 1933 as a competitor to the Boeing 247 . The follow-on DC-2 was del ivered to TWA on May 14, 1934. With a modified fuselage but with the same wing, tails, and engines, a bomber version 
(B-18) was developed from the $D C-2$ in the 1 ate 1930 's. In the same time period, another conversion of the $\mathrm{DC}-2$ with the only changes being a cargo door and a slightly larger tail became the C-33 transport.

- DC-3/DST was designed originally in 1935 as the Douglas Sleeper Transport (DST) to compete with the Curtiss Condor sleeper. The day version was the 21 -passenger DC-3 which became one of the world's greatest transports. Over 11,000 were built including the $C-47$ military transport version. Many of these aircraft are still in service today.

- Lockheed 10/14/18 were twin-engine monoplanes--the 10 (Electra) carrying 10 passengers at $200 \mathrm{mph}$ in 1934; the 14 (Super Electra) carried 12 passengers at $240 \mathrm{mph}$ in 1937; the 18 (Lodestar) carried 14 passengers at $225 \mathrm{mph}$ in 1939. The 18 was al so adapted for military service.

- DC-4E was conceived in 1936 as an enlarged four-engine replacement for $D C-3$. The airplane, only one of which was built, had seats for 52 passengers, weighed 66,500 pounds, and employed triple vertical tails. The airplane, eventualiy sold to Japan, did lead the way to a postwar DC-4.

- Boeing 307 Stratoliner was the last airliner development before WW II. The 33-passenger 4-engine low-wing monoplane was the first pressurized airplane to go into service. The airplane was derived by using the wings, nacelles, engines, and tail surfaces of the B-17 bomber with the only change being the iarge, circular-section pressurized fuselage. Airline service began in 1940 but a year later they were ordered into war service.

- Boeing 377 Stratocruiser developed following WW II as a commercial version of the Air Force C-97 cargo/transport/tanker. The 377 used the wing, tails, and landing gear from the $\mathrm{C}-97$ (and B-29) and the engines froin the $B-50$. The fuselage was converted to a two-level cabin with accommodations for up to 114 passengers. Some were fitted as sleepers with 28 upper and lower berths and the roomy, spacious cab in features have not been dupl icated since.

- DC-4 began its development as a scaled-down version of the abandoned $D C-4 E$. It was immediately pressed into military service as the C-54 Skymaster. The commercial version 1ater entered service in October 1945.

- Constellation was developed by Lockheed for TWA as a long-range transport in the early 1940's but it began its career as the C-69 military transport in 1942. Following WW II, the commercial version began airline service both with TWA and PAA in 1946.

- DC-6 series was an improved follow-on to the $D C-4$ intended to compete with the constellation. The DC-6 went into service in April 1947. The DC-6 was al so produced as the C-118 Liftmaster"military transport. 
- C-124 Globemaster by Douglas was a huge 200-passenger military transport and went into service in 1949. The four-engine propeller-driven airplane had a double-deck fuselage with a built-in nose ramp. No civil version was produced.

- Super Constellation was developed as an improved version of the original "Connie" and with the newly-developed Curtiss-Wright turbo-compound engine went into service with Eastern in December 1951. A military transport version, the $\mathrm{C}-121$, was also produced.

- $D C-7$ series was developed from the $D C-6$ as a competitor for the Super Constellation and first entered service in November 1953. The DC-7 retained the wing of the $D C-6$ but had a lengthened body.

- L.1649A Starliner was a Lockheed development of the Constellation with a completely new larger span wing mated to the Super Constellation fuselage. The 99-passenger airplane went into service in February 1957.

- C-130 Hercules development by Lockheed was begun in 1951 following an Air Force decision to re-equip with turboprop transports. The prototype flew on August 23, 1954 and the first production model flew in April 1955. The $C-130$ has been modified for about 50 specialized applications and was still being funded in the FY $84 / 85$ budgets. As a troop carrier there are accommodations for about 92. Maximum gross weight is about 175,000 pounds. With a maximum payload of about 44,000 pounds, the range is about 2,400 miles at $374 \mathrm{mph}$.

- C-133 Cargomaster by Douglas was the first US heavy strategic transport to use turboprop engines. The huge aircraft $(275,000$ pounds) has a troop capacity of 200 and was large enough to carry Atlas or Titan ICBM's internally. The design started in 1952 and first flight was 1957 . No civil version was made.

- Martin 202/404 resulted from a post WW II effort to replace the DC-3. The 202 was a 42-passenger twin-engine propeller-driven aircraft that went into 1 imited service in 1947. A series of accidents, including a wing failure, plagued the 202. The 404 was a 52-passenger improved version that went into service in 1951. Only about 149 airplanes of both types were built.

- Convair CV-240/340/440 was competing with the Martin 202 family for the same market. The 240 carried 40 passengers and went in service in 1948 followed by the 340 with 44 passengers in 1952 and the 440 with 56 passengers in 1956. More than 1,000 civil and military $(T-29, C-131)$ were built, 240 of which were later re-engined with propeller turbines.

- Lockheed L.188 Electra was the only large civil turboprop airplane built in the US. It was powered by four Allison engines. The Electra carried up to 99 passengers and entered service with American and with Eastern in January 1959. 
- F-27 Friendship has been a highly successful turboprop design. It is a Fokker design that was produced by Fairchild Hiller in the US. With two Rolls-Royce engines, the F-27 first flew in 1955 and entered service in the US in 1958 with West Coast Airline.

- Boeing 367-80 was the first turbojet transport to fly in the United States and that occurred on July 15, 1954. The heritage of the Dash 80, which was the first prototype 707 , had been the Boeing success with larger bombers which emerged from the $X B-15$ (XC-105) long-range experimental bomber XBLR-1 of the late $1930^{\prime} \mathrm{s}$, the Model 255 which became the B-17 (1934), the B-29 (1944), and the B-50 (1947). These were all four-engine propelier-driven airplanes. The knowledge gleaned from Germany lead Boeing to the design of the swept-wing six-jet B-47 which first flew in December 1947, and the swept-wing eight-jet B-52 which first flew in April 1952. The Dash 80 outgrowth was privately financed by Boeing with a view toward commercial passenger use and military tanker use, both of which were achieved. The first of a long and historic series of the 707 family began service with PAA in October 1958. Military derivations of the 707 type airframe are the E-3 sentry (AWACS), E-6, the EC-18 Advanced Range Instrumentation Aircraft (ARIA), the $\mathrm{C}-137$ ( $\mathrm{Air}$ Force One), and the $\mathrm{KC}-135$ Stratotanker.

- Douglas DC-8 was the second US jet transport, built to compete with the Boeing 707. Although Douglas had translated the DC-2 (with a new body) into the $B-18$ bomber, the $B-18$ was replaced by the $B-17$; and Douglas did not successfully proceed into the swept-wing jet-powered bomber world. The DC-8 first fl ew May 30, 1958, and entered servie with Delta and United in September 1959.

- Convair CV-880/990 was the third swept-wing four-jet transport to be built in the US. Although the 880 entered service with Delta in May 1960 and the 990 with American in 1962, the production was limited since Boeing and Douglas had already gained the bulk of the market. The 990 was claimed to be the world's fastest commercial aircraft at $640 \mathrm{mph}$.

- C-141 Starlifter was developed by Lockheed starting in March 1961 following an Air Force design competition with Boeing and Convair for a jet-powered transport. The first C-141 flew on December 17, 1963. Maximum weight was about 317,000 pounds. Range with a 70,550 pound payload was about 3,000 miles. About 154 troops could be carried. A $C-141$ B stretch version flew in December 1979 with a payload capacity increased to 90,000 pounds.

- Boeing 727, the second Boeing jet transport development, was aimed at shorter range flight and smaller field operation. The 727 is a trijet with an array of high-lift devices. Many versions of the 727 have been produced since the flight of the first model on February 9, 1963. 
- Douglas DC-9 gave Douglas the opportunity to produce the first twin-jet short-to-medium-range transport with a first flight February 25, 1965, and service entry with Del ta December 8,1965 . With engines mounted aft on the body, the $D C-9$ has a clean wing design. Many versions have continued to be produced including the $C-9$ military version.

- Boeing 737 was competitor for the small airliner market and first flew on April 9, 1967. The 737 has twin-jets pylon mounted under the wing. The body cross section was maintained the same as that for the 707 and 727 . Airline service began with United in 1968. A military navigation trainer, $T-43 A$, is al so in use.

- Boeing 747 was the first of a new generation of wide-body jumbo jets that essentially was to double the capacity, weight, and power of the first jet transports. The 747, announced in Apri1 1966, first flew February 9, 1969. The airplane has a capacity of up to about 500 passengers, a maximum weight of about 775,000 pounds, and four jet engines each rated at about 50,000 pounds thrust. Many versions of the 747 have been built and it is used as a special duty military aircraft, the E-4.

- McDonnel1-Douglas DC-10 is the tenth in the long line of Douglas transports. The objectives were similar to those for the DC-3--operate economicaliy with a large load of passengers over short and medium ranges using small airports. The $D C-10$ is a wide-body trijet with high-bypassratio turbofan engines. The gross weight is about 430,000 pounds to 550,000 pounds, passenger capacity is up to about 380 . The first model flew in August 1970 and entered service with American on August 5, 1971. There are several versions of the aircraft including a military cargo/tanker KC 10 Extender.

- Lockheed L.1011 Tristar is a wide-body trijet that represents the first Lockheed entry into the major commercial field since the Electra turboprop. The interim years for Lockheed transport types were occupied by military types such as the $\mathrm{C}-130$ Hercules and the $\mathrm{C}-5$ Galaxy. The first L.1011 flew November 16, 1970, and entered service with Eastern on April 26,1972 . The gross weight is about 430,000 pounds to 500,000 pounds with up to about 400 passengers. Size, weights, and performance are similar to that for the $\mathrm{DC}-10$.

- Other major commercial transports which will not be covered in any detail include the Boeing 757 twin-jet medium range for about 200 passengers and the Boeing 767 twin-jet long range for about 300 passengers.

- McDonnell Douglas C-17, now in full-scale development under the FY 86 budget, is intended to meet a USAF requirement for a heavy-lift cargo transport for inter- as well as intra-theater use. The concept uses a blown fl ap system, developed on the $Y C-15$, to achieve short-field performance. The YC-15 first flew on August 26, 1975. The C-17, with an expected IOC of about 1990, would have a range of about 2,700 miles with a 
payload of 172,200 pounds and operate from field lengths of about 3,000 feet.

Some Comparisons

Military Transports. - A comparison of some of the major current military transports of the USSR and the USA is shown in Figure 9. The range in size and capacity is fairly similar--the $A n-12$ Cub and $C-130$ Hercules are comparable; the I1-76 Candid and C-141 Starlifter are comparable; the An-22 Cock is distinctive in its size, range, and payload capability and in its efficient turboprop power plant; the $\mathrm{C}-5$ is distinctive in its size, range, payload, and troop-carrying capability making it the world's 1 argest operational transport-type aircraft. However, with the appearance of Condor, which is not quite operational as yet, the USSR will possess the world's largest aircraft with a cargo and passenger capacity exceeding that of the C-5. A comparison of the An-124 Condor and C-5A Galaxy is shown in Figure 10. The Condor appears to have a wing of higher aspect ratio and a slightly higher sweep. The horizontal tail is larger and is body-mounted rather than T-mounted on the vertical tail. The wing has conventional ailerons, singleslotted Fowler flaps, leading-edge flaps, and upper-surface spoilers. The tail has fixed-incidence and an elevator.

Some other distinctive features that might be noted are:

- There appears to be a greater emphasis on the part of the USSR for STOL operation and operation from unprepared airfields. Whereas most US military transports are designed for improved runways, Soviet transports are generally designed for unimproved fields through the use of multiwheels, short and sturdy landing gear, low-pressure tires or variablepressure tires, some of which can be adjusted in flight. Soviet military transports generally have high thrust-to-weight ratio engines, good flap designs, and have been known to make use of rocket-assisted takeoff. The early adoption of upper-surface blowing with the An-72 follows the pattern for STOL.

- The Soviets strive for autonomous operation with military transports with the use of internal loading handling equipment, adjustable floor-loading heights, self-starting engines, gravity fuel loading, on-board test equipment, and generally simple rugged design and construction.

- Extreme ends of the airlift spectrum will apparently soon be met by the An-72 Coaler on the one extreme and the An-124 Condor on the other.

It begins to become obvious that worldwide airlift capability is important to the USSR as a necessary part of translating political policy into military action if necessary. It should al so be noted that the airlift capability is greatly enhanced by the existence of the state-owned civil airline system Aeroflot since all assets of Aeroflot--aircraft, crews, and facilities are immediately available for military use. 
Civil. Transports.- The general trend for civil transport development has followed essentially the same pattern. Early transports had strong foreign influences in both the USSR and the US. For all practical purposes, the air travel system in existence today began essentially with the same airplane, the $D C-3$ in the US and the $L i-2$ in the USSR. The progression in airliner development from that point on has been quite similar with only a few exceptions--the USSR making greater use of turboprops, for example; the US advancing to wide-body jumbo jets more rapidly; the USSR proceeding further into civil supersonic applications than did the US.

The types of civil transports developed in the USSR have, for the most part, been designed to meet the transportation needs of the country as seen by the government. The types of transports developed in the US have in some cases been those designed to meet the requirements of a particular air carrier and in some cases have been developed by industry as a means of creating a competitive a tmosphere.

\section{Some Observations of Design Trends}

USSR civil aircraft design trends have not been drastically different from US design trends. Indications from Soviet writings are that the current thinking is not vastly different from that of the US. Some current Soviet articles regarding civil aircraft design point out that the primary problem facing civil aircraft designers is the need to reduce fuel consumption.

Design features being considered for improved fuel consumption are:

- Turboprops of new design with multi-curved blades (UDF).

- Reduction in empty weight through the use of new materials (composites) and new manufacturing techniques.

- Improved aerodyanmics with higher aspect-ratio wings, wing-tip devices (winglets), and new airfoil profiles (natural laminar flow).

- Improved production technology to el iminate surface irregularities.

- Improved operational techniques including optimum flight trajectories and electronic flight management systems.

- Improved high-lift devices in combination with improved engines to provide for STOL aircraft.

Design characteristics of USSR and US transports appear to be governed more by ideological differences rather than by technological differences. Technical capability exists in both countries. Technology advances are generally introduced more rapidly in US aircraft in an effort to provide a product having a competitive edge on the market and thus provide a sound economic base for the producer. The economic motivation, as such, does not exist in the USSR and emphasis is placed on 
meeting national objective requirements which often can best be done through the use of existing and proven technology followed by evolutionary improvements. A competitive atmosphere does exist in the Soviet aircraft industry but the prime motivation is not economics but rather the desire to maintain credibility with the government/party and thus prevent extinction.

The acquisition of western technology or the seemingly imitation of western products by the USSR does not necessarily reflect a lack of ability. Innate talent does exist and the education and training standards provide a rich supply of qual ified workers. However, it is not uncommon for the Soviets to accelerate their progress wherever possible through the use of work done by others that may be obtained either through open channels or by covert means.

\section{Concluding Remarks}

Concluding remarks can only be considered as remarks--definitive conclusions concerning the relative status of US and USSR aircraft is considered to be a hazardous undertaking that would likely become more subjective that objective. However, the fundamental indications seem to be that the status and functionalism of US versus USSR civil and military transport-type aircraft are more a matter of ideological differences rather than technological differences. That is to say that the Soviet system is one in which a national level functional requirement is set and an expedient solution to meet the requirement is developed, rather than being a system in which technological advancements are developed for which an application is then sought. Some features of the Soviet system for aircraft development are:

o Highest government levels support the aircraft industry.

- Separation of design and production.

- Research institutes supply handbooks that control approved aerodynamic designs, structural methods, and available materials.

- Emphasis on competition at all levels including prototyping.

o Simplicity, commonality, and continuity predominate.

Common to both the US and the USSR are:

- Developments from civil to military systems as well as from military to civil systems.

- Numerous modifications of some designs.

- Several design types to cover a broad range of objectives.

Some differences in US and USSR systems: 
- The USSR has made greater use of turboprop designs.

- The USSR has placed greater emphasis on unprepared field operation.

- The USSR has placed greater emphasis on STOL operation.

- The USSR has advanced farther in SST development thus far.

- The US has advanced farther in wide-body jumbo jet civil transports.

Suffice it to say that a great deal of attention has been paid to the development of civil and mil itary transport aircraft, both large and small, in the US and the USSR since the early $1900^{\prime} \mathrm{s}$. Developments have been notable in both countries. The nature and timing of the developments have varied but it appears that the objectives and requirements of the two countries, while being different, have been achieved. Further, there is no indication that progress has slowed in the area of transport aircraft but, indeed, there are signs of growth in both the US and the USSR.

\section{Bibl iography}

The International Encyclopedia of Aviation, Crown Publishers, Inc., New York, NY, 1977.

World Military Aviation, Nikolaus Krivinyi, Arco Publishing Co., Inc., New York, NY, 1977.

Soviet Aircraft and Rockets, Transport Publishers, Moscow, 1971.

The History of the US Air Force, David A. Anderton, Crescent Books, New York, NY, 1981.

Soviet Aviation and Air Power, A Historical View, Westview Press, Boulder, Co, 1977.

The Soviet Air Force Since 1918, Alexander Boyd, Stein and Day, New-York, NY, 1977.

Pioneers of Flight, Henry T. Wallhauser, Hammond, Inc., Maplewood, NJ, 1969.

Aircraft of the USAF, Sixty Years in Pictures, Paul Ellis, Jane's Publishing Co. Ltd., London, 1980.

Progress in Aircraft Design Service 1903, NASA Langley Research Center, Hampton, VA, 1974.

United States Airlines: Trunk and Regional Carriers, Their Operations and Management, Leo G. Fradenburg, Kendal1/Hunt Publishing Co., Dubuque, IA, 1980. 
Aircraft of Langley Air Force Base, 1917-77, Office of TAC History, Headquarters Tactical Air Command, Langley AFB, VA, 1977.

Aviation Week and Space Technology, published weekly, McGraw-Hill, Inc., New York, NY.

Soviet Military Power, Department of Defense, 1985.

Soviet Aerospace Almanac, Air Force Magazine, published annually in March.

The Military Balance, Air Force Magazine, published annually in December.

Soviet Air Power in Transition, Robert P. Berman, The Brookings Institute, Washington, DC, 1978.

World Aircraft, Military, 1945-60, Enzo Angelucci and Paolo Matricardi, Rand MCNally and Co., Chicago, IL, 1980.

Role of Aerodynamics in Tupolev, Ilyushin Aircraft Designs, G. Yudin, Grazhdanskaya Aviatsiya, No. 6, June 1984, pp. 34-35, Moscow.

Arms, Men, and Military Budgets, Issues for Fiscal Year 1981, National Strategic Information Center, Inc., New York, NY 1980.

Designer on Civil Aircraft Design Trends in USSR, S. Yeger, Nedelya, No. 33, August $13-19,1984$, pp. 12-13, Moscow.

Soviet Airlift: Coming of Age, Major Lee Nelli, Airlift, The Journal of Airlift Operations, Vo1. IV, No. 3, Summer 1982, Scott AFB, IL, 1982.

Soviet Life, published monthly, Embassy of the Union of Soviet Socialist Republics, Washington, DC. 


\begin{tabular}{|c|c|c|c|c|}
\hline Antonov & Beriev & Ilyushin & Tupolev & Yakovlev \\
\hline $\begin{array}{l}\text { An-2 Colt } \\
\text { An-8 Camp } \\
\text { An-10 Cat } \\
\text { An-12 Cub } \\
\text { An-14 Clod } \\
\text { An-22 Cock } \\
\text { An-24 Coke } \\
\text { An-26 Curl } \\
\text { An-28 Cash } \\
\text { An-30 Clank } \\
\text { An-72 Coaler } \\
\text { An-124 Condor }\end{array}$ & Be- 30 Cuff & $\begin{array}{l}\text { II-12 Coach } \\
\text { II-14 Crate } \\
\text { II-18 Coot } \\
\text { II-62 Classic } \\
\text { II-76 Candid } \\
\text { II-86 Camber }\end{array}$ & $\begin{array}{l}\text { Tu-70 Cart } \\
\text { Tu-104 Camel } \\
\text { Tu-110 Cooker } \\
\text { Tu-114 Cleat } \\
\text { Tu-124 Cookpot } \\
\text { Tu-134 Crusty } \\
\text { Tu-144 Charger } \\
\text { Tu-154 Careless }\end{array}$ & $\begin{array}{l}\text { Yak-40 Codling } \\
\text { Yak-42 Clobber }\end{array}$ \\
\hline
\end{tabular}




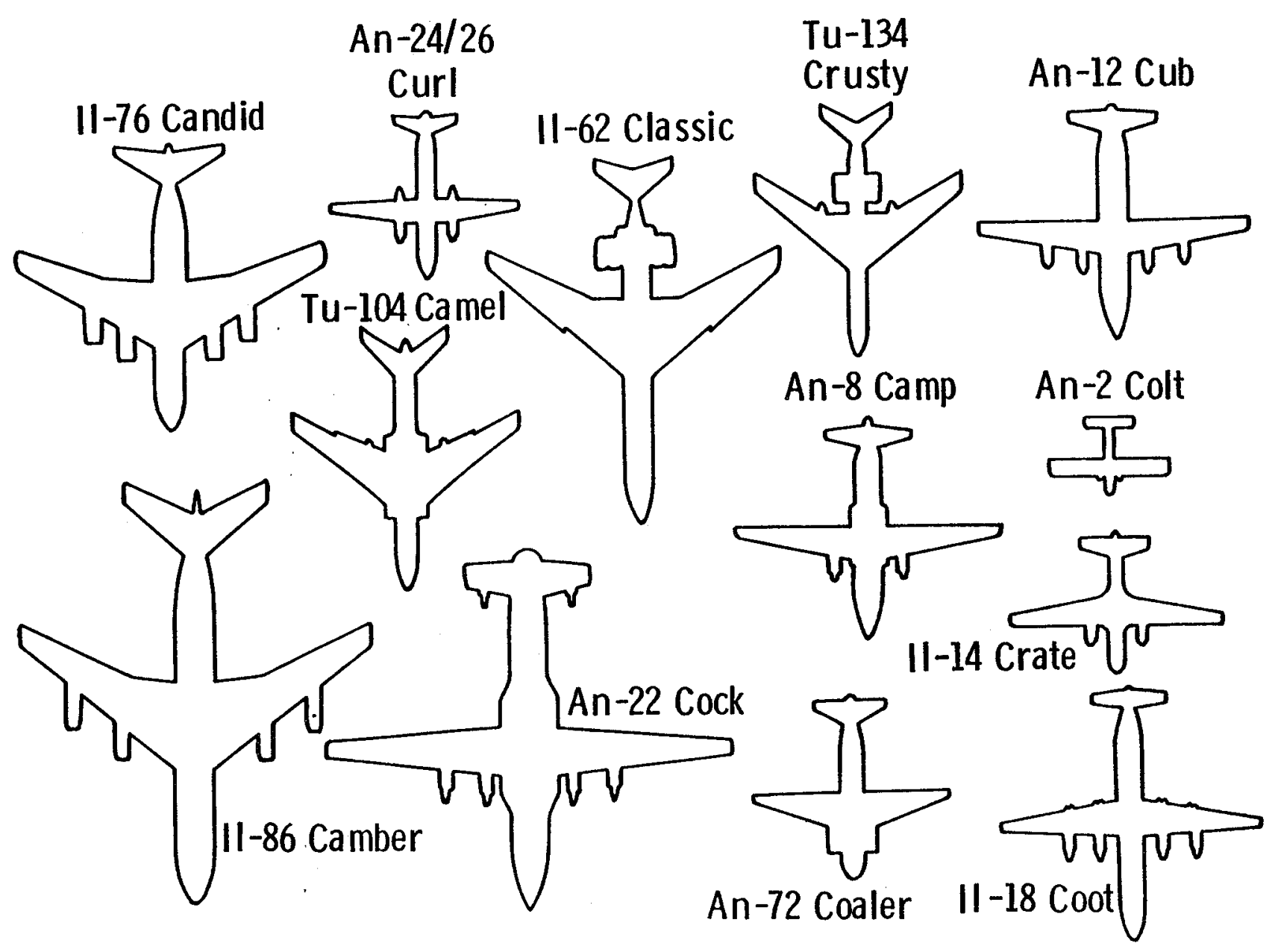

Figure 2.- Some USSR transport types. 


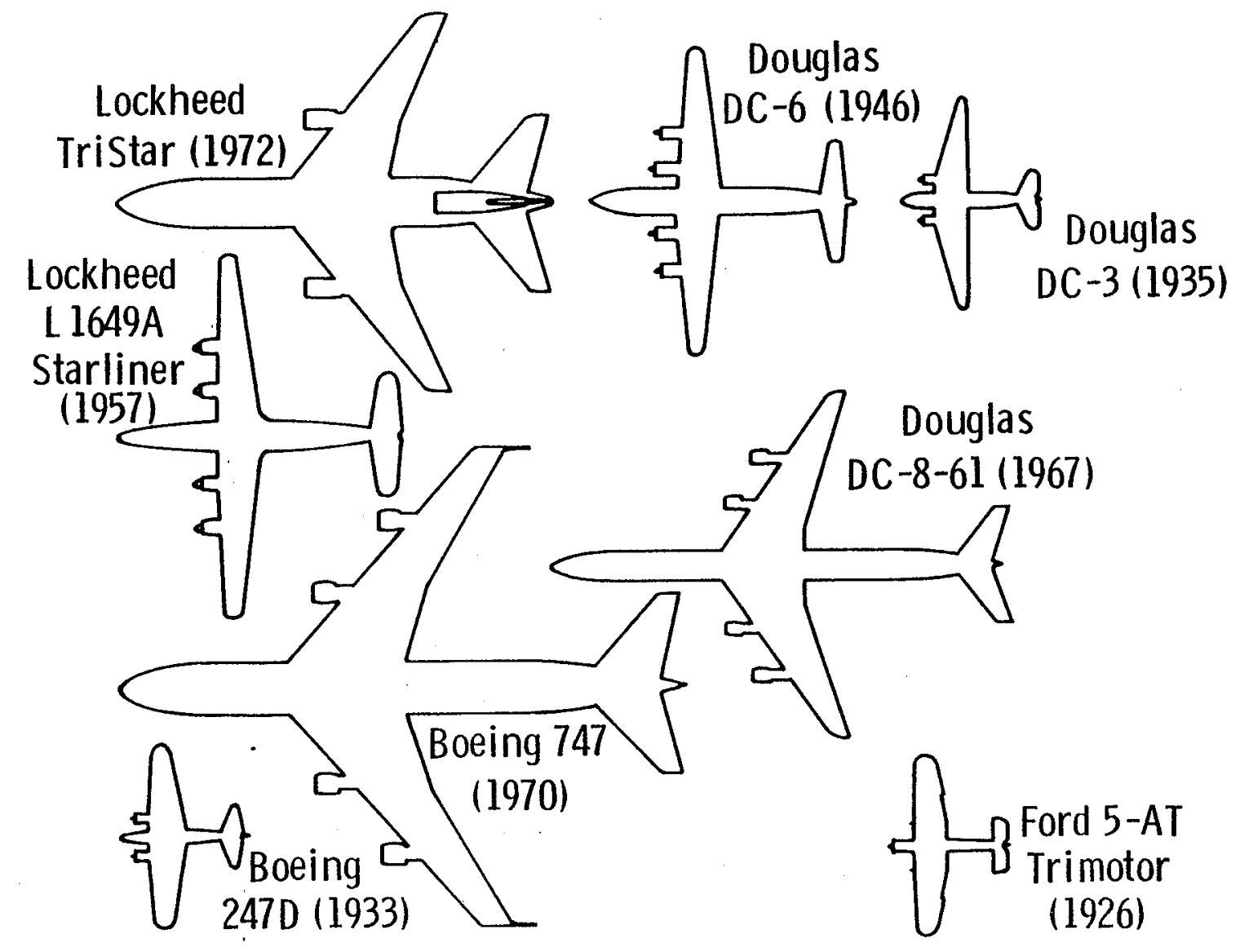

Figure 3.- Some US transport types. 


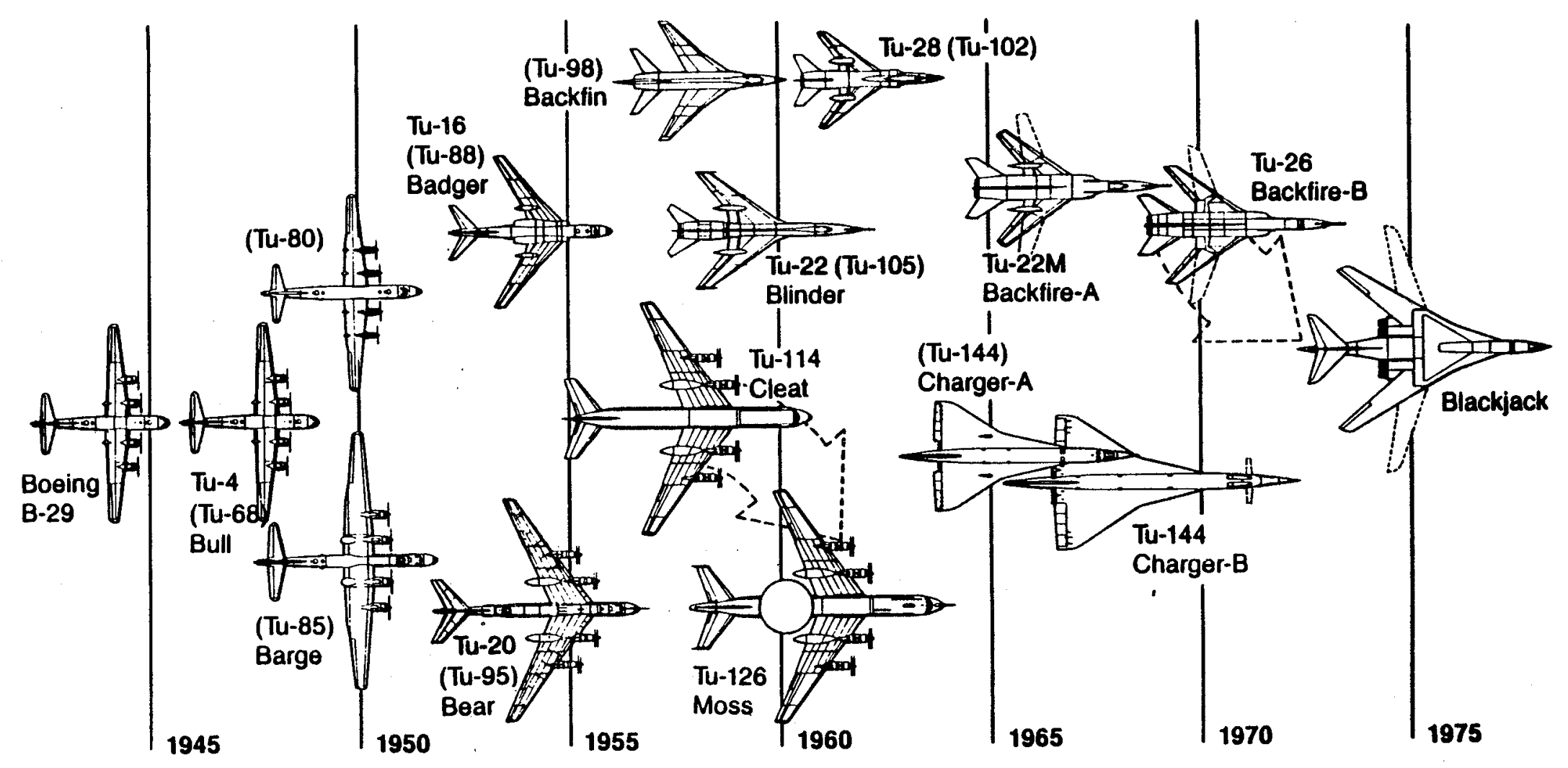

Figure 4.- Tupolev major designs since 1945. 


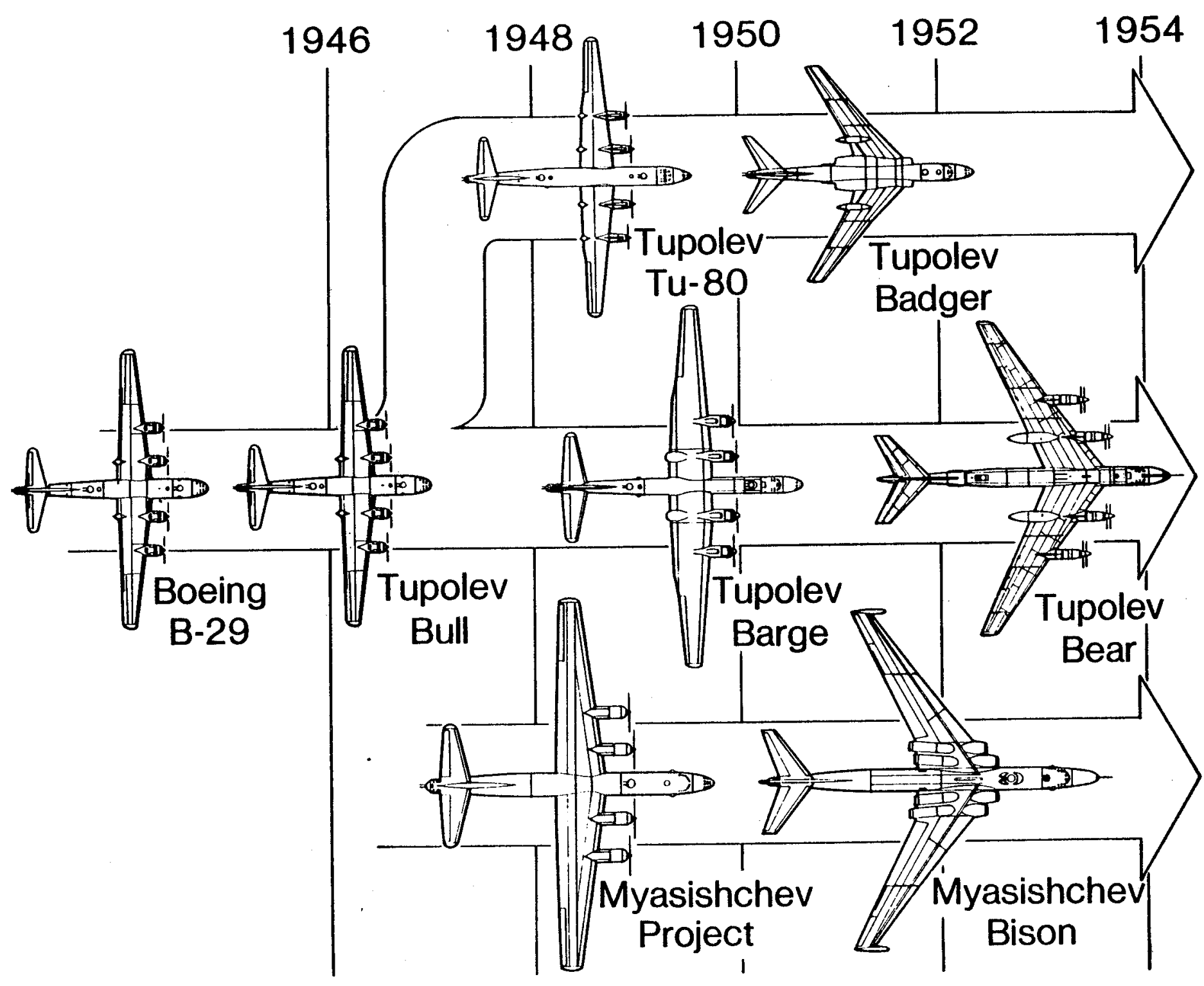

Figure 5.- Long range USSR bonbers, 1945-1954. 


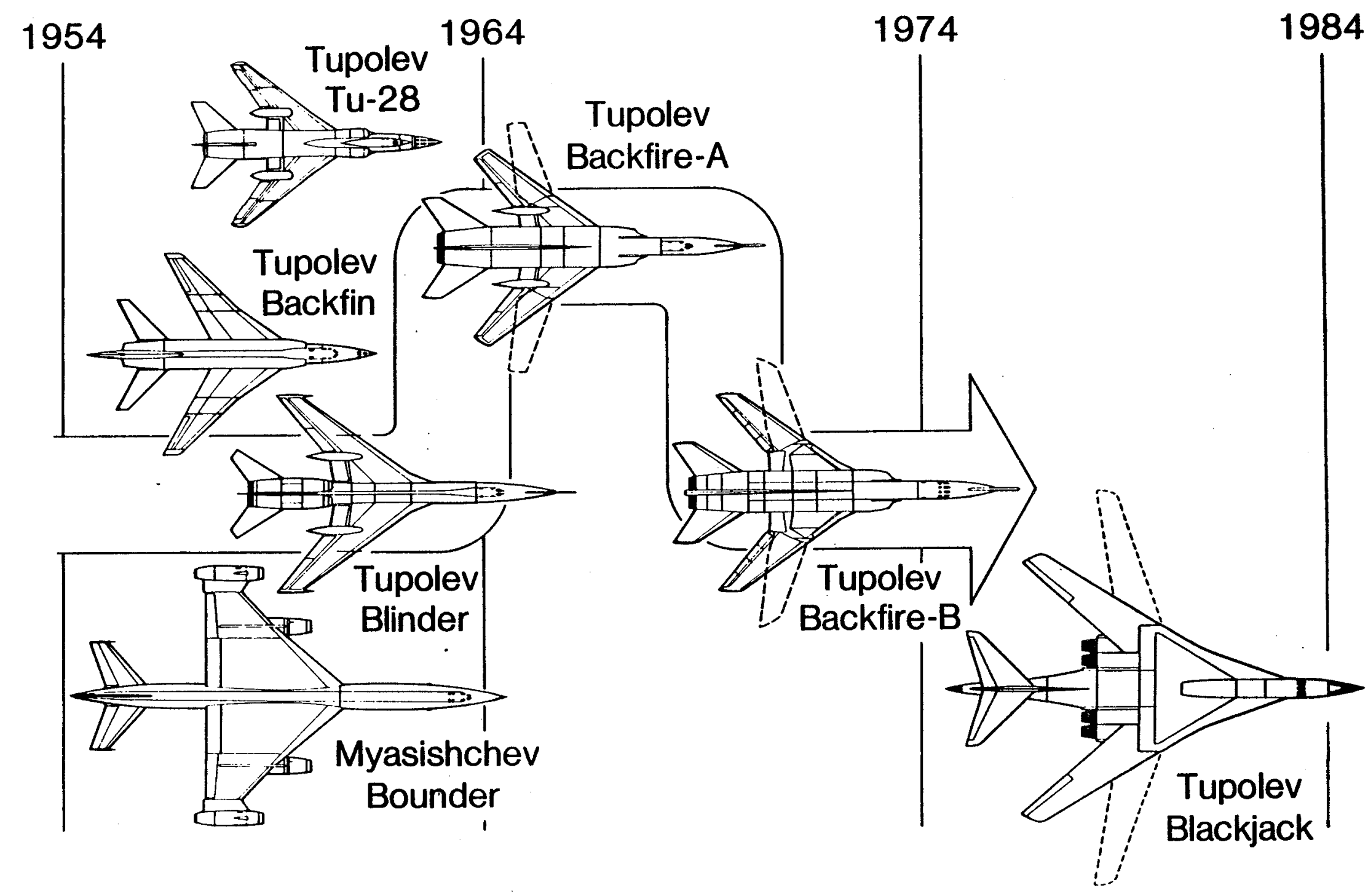

Figure 6.- Principal USSR bombers since 1954. 


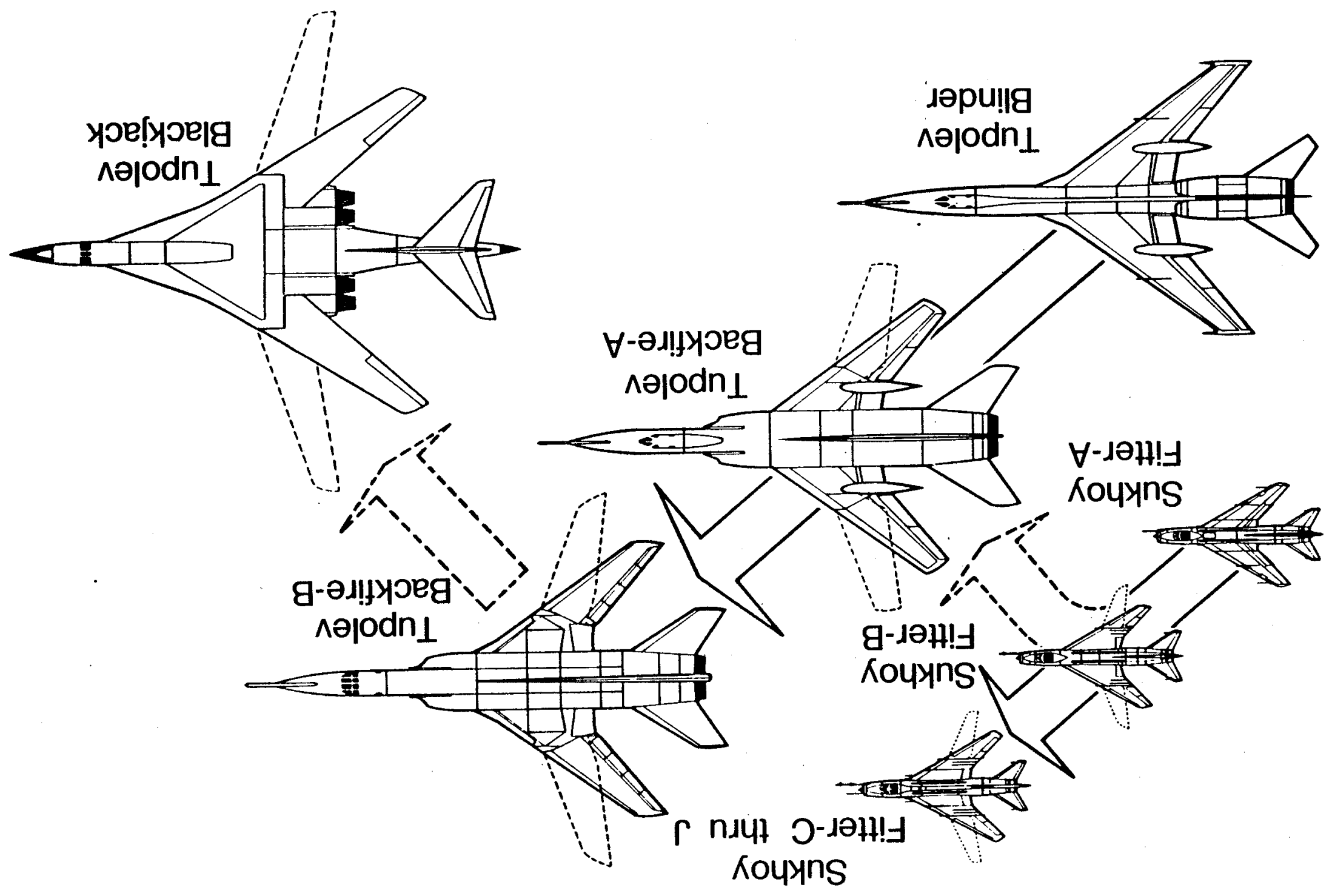




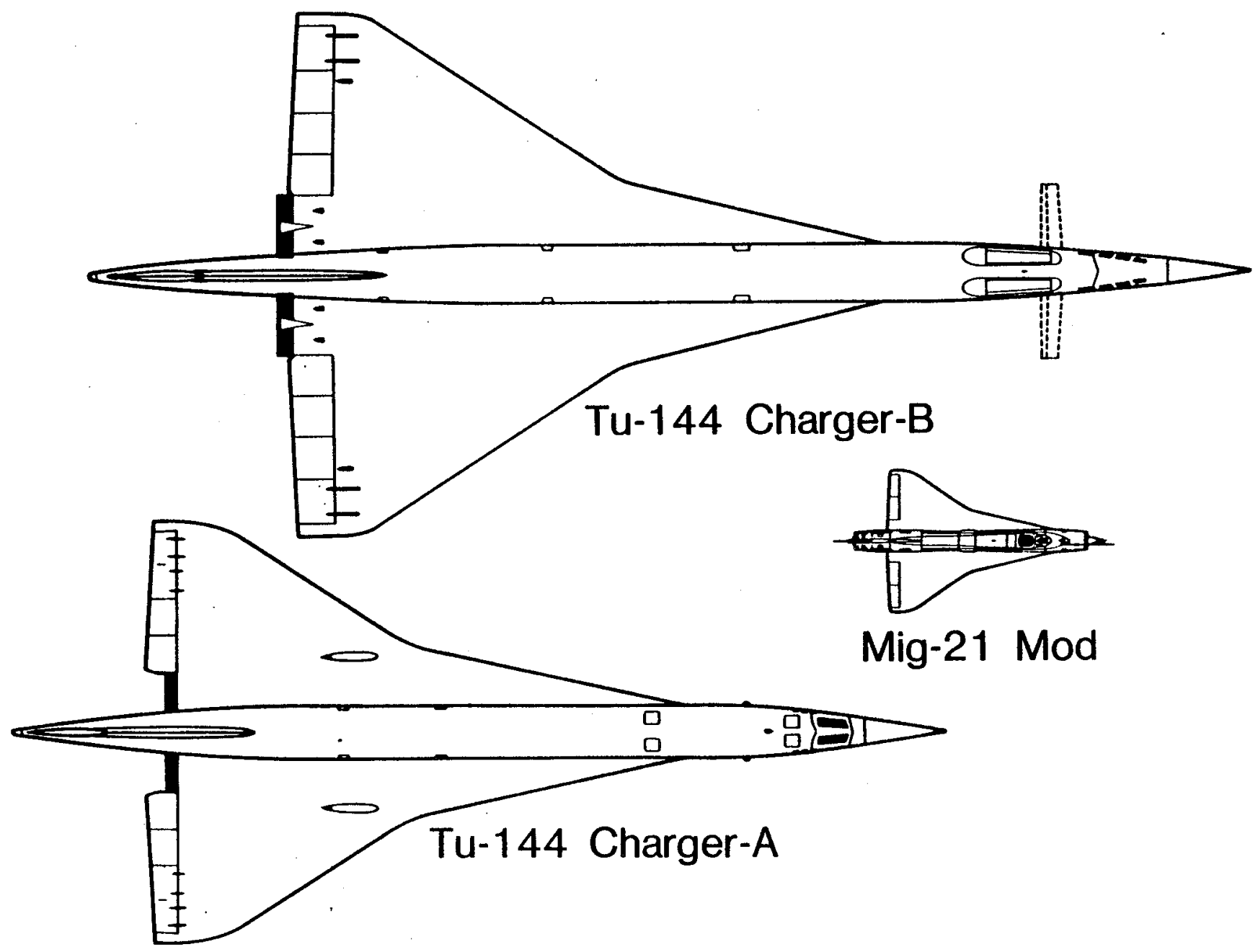

Figure 8.- ISSR SST development 


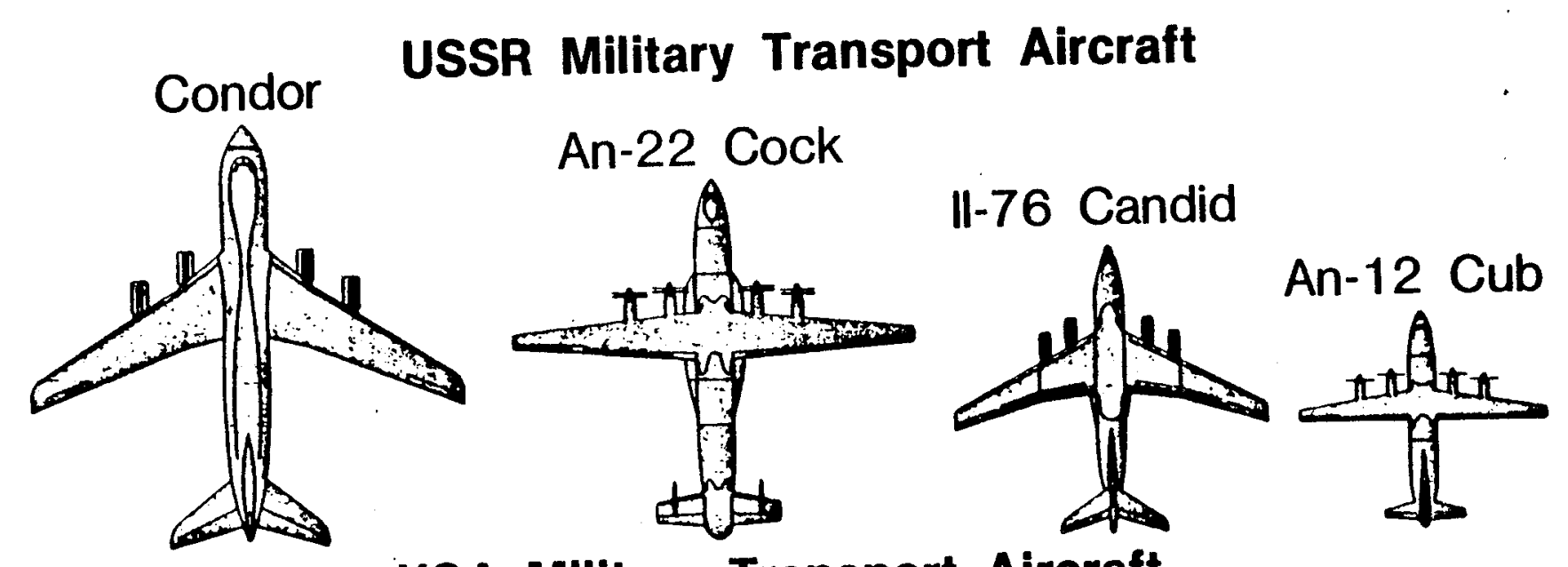

USA Military Transport Aircraft

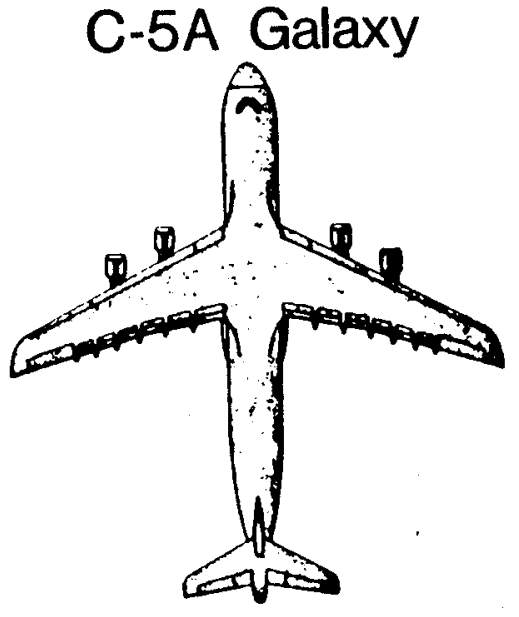

C-141B Starlifter

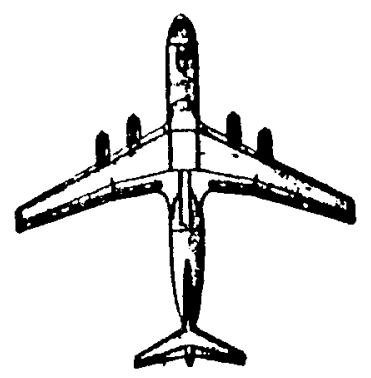

C-130 A/H Hercules

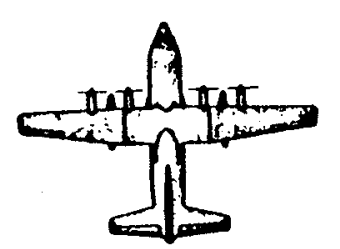

Figure 9.- Major military transports of USSR and US. 


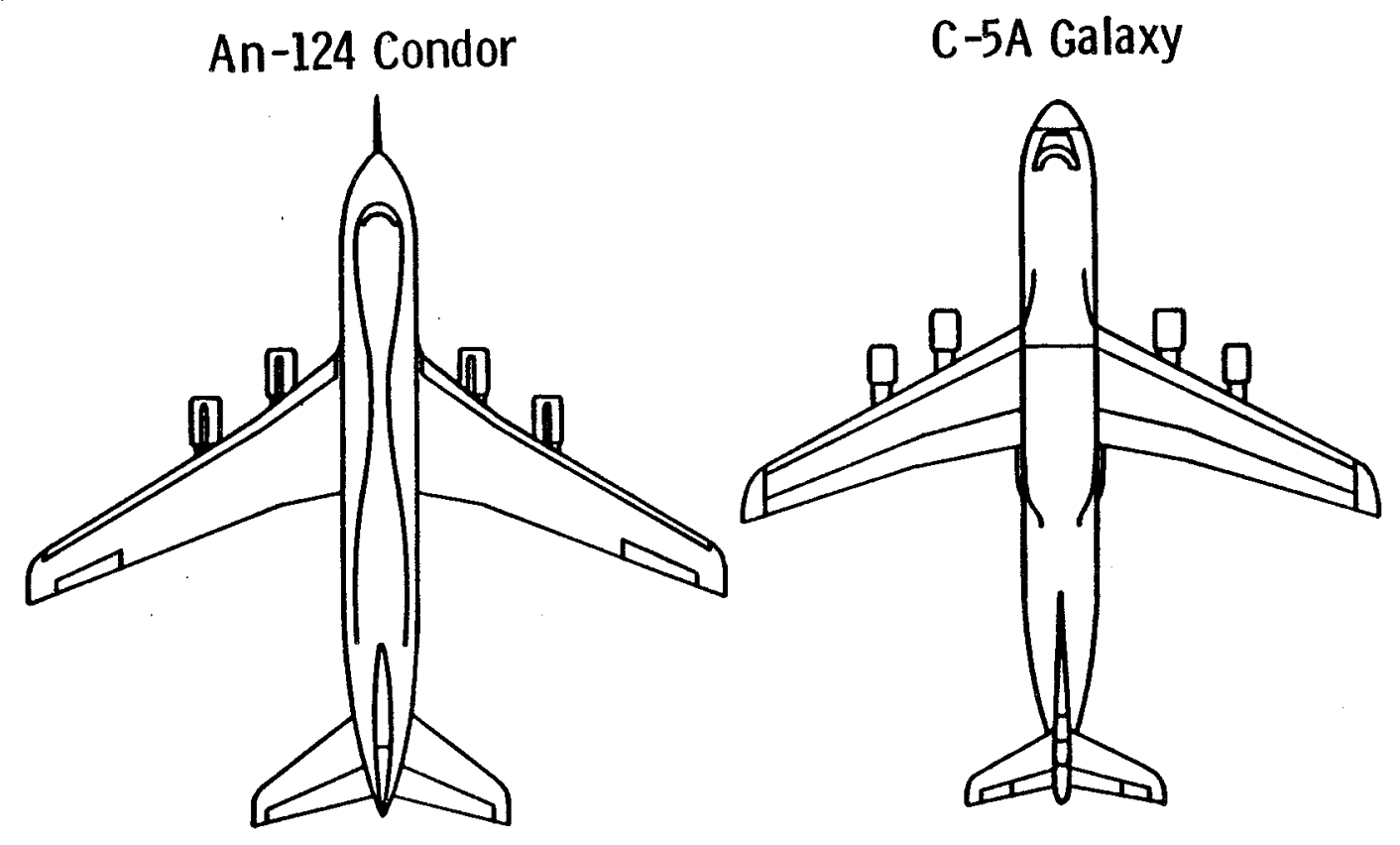

Figure 10.- Comparison of An-124 Condor and C-5A Galaxy. 
Standard Bibliographic Page

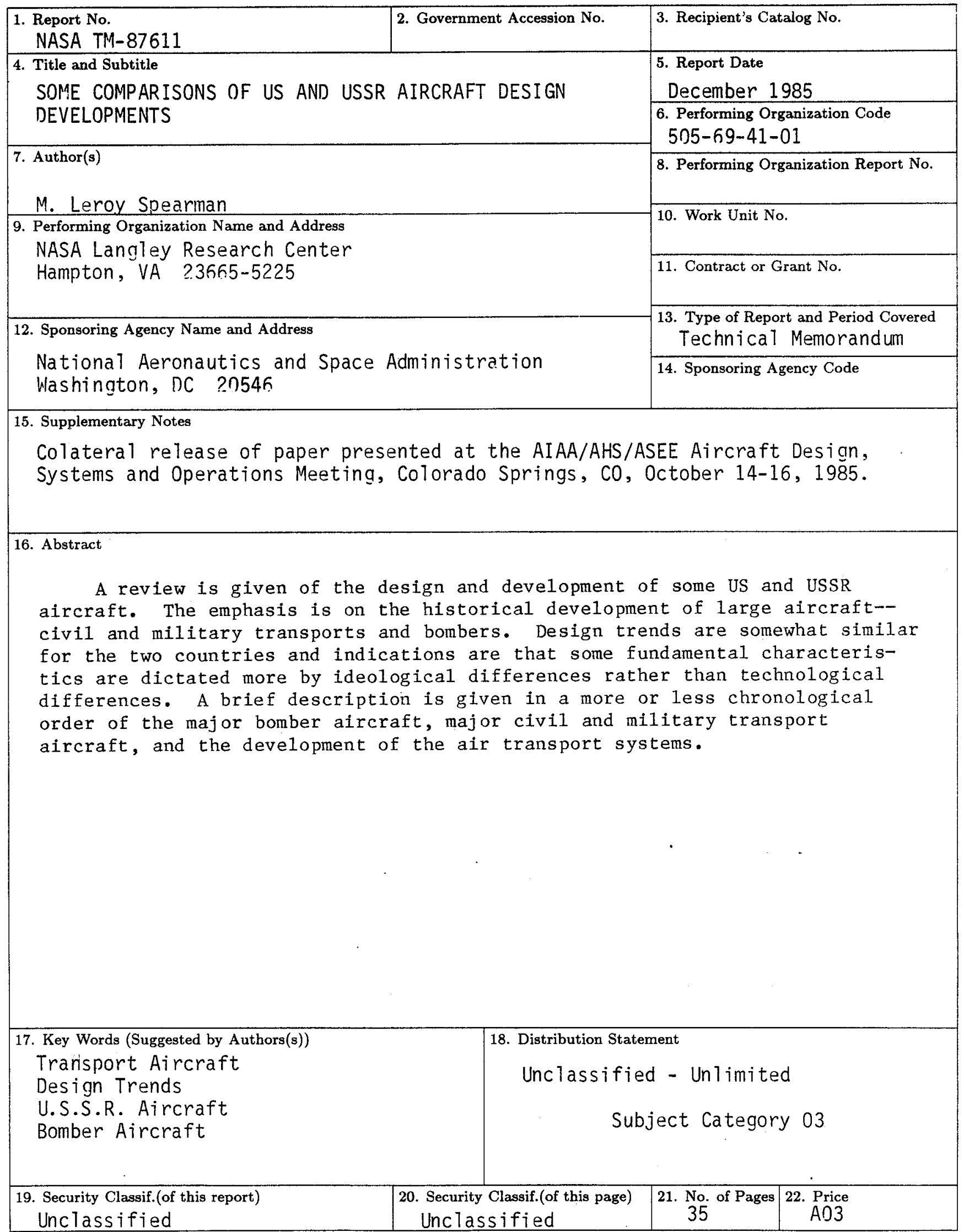

For sale by the National Technical Information Service, Springfield, Virginia 22161

NASA Langley Form 63 (June 1985) 
